\title{
A Longitudinal KAP Study on HPV Immunised Adolescents' in Malaysia
}

\author{
Abdul Nazer Ali ${ }^{1 *}$, Jong Shi Jie ${ }^{1}$, Sunil Kumar Prajapati ${ }^{1 *}$, Mohd. Zahid Iqbal ${ }^{1}$, \\ Nazer Zulfikar Ahmed ${ }^{2}$ and Thamir M. Alshammari ${ }^{3}$ \\ ${ }^{1}$ Faculty of Pharmacy, AIMST University, Malaysia; \\ abdul.nazerali16@gmail.com, jsj_6118@hotmail.com, clinical.sunil@gmail.com,drmmziqbal@gmail.com \\ ${ }^{2}$ Cognizant Technology Solutions India Private Limited, Hyderabad - 500019, Telangana, India; \\ n.zulfik@gmail.com \\ ${ }^{3}$ Department Pharmacy Practice, University of Hail, Saudi Arabia; \\ thamer.alshammary@gmail.com
}

\begin{abstract}
Introduction: Human Papilloma Virus (HPV) infection is the most frequently encountered sexually transmitted disease. Lack of HPV knowledge and vaccination intentions are the main concern for its high prevalence. The primary outcome measure were to assess the Knowledge, Attitude and Perception (KAP) levels among HPV vaccinated secondary school adolescents and estimate the impact of educational intervention through repeated measures. Methods: A longitudinal study was performed using pre-validated questionnaire and educational pamphlet as study and intervention tools. The survey was conducted in three phases, $(0, .5$ and 3-6 months). The scores were categorized based on original blooms cut-off scale. Descriptive statistics for categorical data and Friedman's test for repeated measures followed by pos hoc Wilcoxon signed rank test with Bonferroni correction (type-1 error) was used for inferential statistics. Result: The research findings showed significant differences $(p<.001)$ in KAP scores, observed at all three phases (ph). The KAP scores were $58 \%$, moderate at ph1, 67\% good at ph2 and 59\% good at ph3. The knowledge scores were, $63 \%$ poor at ph1, $64 \%$ good at ph2 and $64 \%$ good at ph3. An estimate for impact of intervention for knowledge gain revealed, a significant ( $p<.001$ ) overall median knowledge score of $9(6)$ and $15(4)$ between ph1 and ph2, respectively. The knowledge retention showed significant differences $(p<.001)$ in median scores, $9(6)$ and $15(7)$ between ph1 and ph3, respectively. Conclusion: Educational pamphlet significantly increased knowledge and KAP scores about HPV in the study population, regardless of socio-demographic characteristics among the study population. Effective, informative and appropriate educational protocols designed for the target population using 'Spaced Repetition-Based Educational Intervention' are particularly important for better and sustained outcomes.
\end{abstract}

Keywords: Adolescents, Human Papilloma Virus, HPV Vaccination, KAP, Repeated Measures

\section{Introduction}

HPV infection invades every sexually active human, at least once in their life time and young adults are especially at higher risk (50\%) for Cervical Cancer (CC) in Asia Pacific region-1. Though, more than $140 \mathrm{HPV}$ types are identified, strong evidence has been observed for two high risk types-16 and 18 ( $>70-80 \%$ of all cases)

\footnotetext{
${ }^{*}$ Author for correspondence
} 
connecting to Cervical Cancer-2. The major risk factors include; history of STDs, multiple sex partners, sex at young age and promiscuous male partners ${ }^{3}$.

Centre for disease control reported, among 38,793 females and males diagnosed annually with HPVrelated cancers, 7.4/100,000 were Cervical Cancer ${ }^{4}$. Among the Malaysian women aged above 15 years, 2145 are diagnosed and 621 die due to Cervical Cancer every year with an annual economic burden of RM312 million towards prevention ${ }^{5,6}$. Even with the national HPV immunization and CC screening in place, the death rates are still not decreased to desired levels due to lack of resources, awareness and infrastructure in rural areas $^{7}$.

Prevention through early detection and treatment, proper condom use and limited sexual partners can reduce risk ${ }^{8}$. A Thailand study reported $74 \%$ male and $70 \%$ female students aged $12-15$ years were not aware about screening for $\mathrm{CC}^{8}$. Furthermore, an England study indicated little knowledge about HPV, the vaccine and need for screening among $50 \%$ of vaccinated girls ${ }^{9}$. A number of studies focus on female's knowledge of HPV and vaccine, but paucity among males does prevail ${ }^{10}$. Lack of knowledge towards HPV infection and vaccine is the main concern for its high prevalence ${ }^{11}$.

The outcome measures were to assess the Knowledge, Attitude and Perception (KAP) ${ }^{12}$ levels among HPV vaccinated (immunised) secondary school adolescents and to estimate the impact of educational intervention on KAP over time.

\section{Method and Material}

This longitudinal study used convenience sampling with a single factor time and KAP as dependent variable using the same questionnaire at three time points. The study populations included were HPV vaccinated secondary school students (at-least 1 dose), aged 13, 14 and 16 years (as permitted by Ministry of Secondary Education, Malaysia) and those participated in all three phases. All other ages between 9 and $>18$ years, incomplete survey forms, not HPV vaccinated and those participated in pilot studywere excluded. The study was conducted between April and December, 2014.

In phase-1, survey forms (questionnaire) were distributed in class room setting and completed forms were retrieved followed by distribution of educational pamphlet. The phase-2 survey was conducted after two weeks. The phase- 3 survey was conducted between three and six months ( $0, .5$ and 3-6 months).

The sample size was calculated based on prevalence of adolescent population in Kedah state, using Raosoft on-line sample size calculator. The estimated sample size was calculated at $95 \% \mathrm{CI}, 5 \%$ margin of error and $50 \%$ response distribution. The required sample size was $\mathrm{N}=$ 384 , further $30 \%$ added for drop-outs and rounded off to 500 to achieve recommended sample size $(\mathrm{N}=500)$.

\subsection{Development of Questionnaire and Educational Pamphlet}

The educational pamphlet was developed to address informations related to HPV infection, cervical cancer, its screening and vaccination ${ }^{13,14}$. Questions in the knowledge section included: definition; epidemiology; progression of infection; signs and symptoms; diagnosis; risk factors; prevention and treatment of HPV infection and related cancer ${ }^{15,16}$.

\subsection{Validation of the Questionnaire}

The initial draft of 30 item questionnaire, was content validated by six experts, face validated by potential respondents and subjected to Known-Group's validity. The online readability test confirmed easy readability and understanding ability among 13 years old. A testretest study was done among two groups and Spearman's correlation showed moderate to strong correlation between pre- and post-test respectively. The MannWhitney test indicated the total score differences were significantly higher for post-test than pre-test. Further, the Intra-class Correlation Coefficient (ICC) for the KAP questionnaire showed good to excellent reliability with significant correlations ${ }^{17}$. Finally, Cronbach's alpha test was conducted among potential respondents 
and two knowledge based questions removed due to negative correlations. The alpha value for the final, 28 item questionnaire was $.947[\mathrm{Mdn}=31(3)]$ with strong positive correlation and excellent reliability ${ }^{13}$.

\subsection{Translation of Questionnaire and Educational Pamphlet}

The developed questionnaire and pamphlet was forward and backward translated with the help of linguistic specialists from a private university. The translated Malay version was cross matched, verified and back translated to English to confirm clear and easy understanding. The inter-rater reliability test (Cohen's $\kappa$ ) was run to determine agreement of translation between the two versions and a strong agreement was observed.

\subsection{Scoring Grades and Scoring Pattern}

The scoring grades were adopted from Original Bloom's cut off points, $80-100 \%$ correct response was good, 60 $79 \%<60 \%$ was poor ${ }^{12}$. The sum of total knowledge score and total attitude and perception score represented total KAP score. One mark for each correct response of 18 knowledge items and the 10 attitude and perception domains were assessed using five point Likert scale, 1 mark for negative marking and 5 marks for positive marking.

\subsection{Ethical Considerations}

The research proposal along with the study instruments was submitted to AIMST University Human Ethical Committee and the ethical clearance was obtained. Further, permission from: Ministry of Secondary Education, Kuala Lumpur, Malaysia and District Education Officer, Kedah state was obtained before initiating the study.

\subsection{Statistical Analyses of Data}

The data analysis was performed using IBM SPSS Statistics for Windows (SPSS version 23). Descriptive statistics for categorical variables was computed using frequency and percentage. Numerical data (distribution not normal) presented as median (IQR). The Chi-square test used for associations. The inferential statistics using Friedman's test and pair-wise application of Wilcoxon signed rank test with Bonferroni correction was used to estimate the precise differences. The significance level was set at .05 for all tests and $\mathrm{p}$ values $<.05$ considered significant. All percentages displayed in text or parentheses are with no decimal places.

\section{Results}

\subsection{Response Rate}

A total of 13,000 survey forms were distributed among vaccinated adolescents and the overall response rate was $23 \%(2928 / 13,000)$. The drop-outs were mainly due to absenteeism, unavailable for all three study phases, incomplete survey forms or violated the inclusion criteria.

\subsection{Socio-Demography}

The median (IQR) age of respondents $(\mathrm{N}=2928)$ was 14(3) years. Majority of respondents were 13 year old; females; Malay; Form-1 education and from rural location (Table 1).

\subsection{KAP Score Differences among Socio- Demographic Variables}

The minimum possible KAP score was 10 and maximum 68. The KAP scores were categorised as poor, moderate and good for each phases as summarized in Table 2.

At ph-1 study, the total KAP score was good among $34 \%$ adolescents aged 16 years; $29 \%$ females; $24 \%$ Malay; $34 \%$ Form- 4 education and $24 \%$ rural area respondents. At ph-2, the total KAP score was good among $78 \%$, aged 16 years; 74\% females; 69\% Malay; 78\% Form-4 education and $69 \%$ urban area respondents. At ph3 , the total KAP score was good among $70 \%$, aged 16 years; $64 \%$ females; $60 \%$ Malay; $69 \%$ Form- 4 education and $62 \%$ rural located respondents. The study observed 
Table 1: Socio-demographic characteristics of respondents

\begin{tabular}{|c|c|c|}
\hline Variables & Frequency $(\mathrm{N}=2928)$ & Percentage (100) \\
\hline \multicolumn{3}{|c|}{ Age in Years } \\
\hline 13 & 1143 & 39 \\
\hline 14 & 939 & 32 \\
\hline 16 & 846 & 29 \\
\hline \multicolumn{3}{|c|}{ Gender } \\
\hline Male & 1002 & 34 \\
\hline Female & 1926 & 66 \\
\hline \multicolumn{3}{|c|}{ Race } \\
\hline Malay & 2621 & 89 \\
\hline Chinese & 105 & 4 \\
\hline Indian & 184 & 6 \\
\hline Others & 18 & 1 \\
\hline \multicolumn{3}{|c|}{ Educational Level } \\
\hline SMK- Form 1 & 1144 & 39 \\
\hline SMK- Form 2 & 938 & 32 \\
\hline SMK- Form 4 & 846 & 29 \\
\hline \multicolumn{3}{|c|}{ Location } \\
\hline Rural & 1916 & 65 \\
\hline Urban & 1012 & 35 \\
\hline
\end{tabular}

significant differences in KAP scores among all sociodemographic categories in all three phases $(\mathrm{p}<.05)$ except location in ph2 (Table 2).

\subsection{The Overall KAP Score Comparison at Three Time Points}

The median KAP score at ph1 was $47(12)$, with $58 \%$ scoring moderate $[X 2(2, \mathrm{~N}=2928)=839, \mathrm{p}<.001]$. The median KAP score at ph2 was 57(10), with $67 \%$ scoring good $[X 2(2, \mathrm{~N}=2928)=1679, \mathrm{p}<.001]$. At ph3, the median KAP score was 56(13) and 59\% scoring good $[X 2(2, N=2928)=1022, \mathrm{p}<.001]$. Significant differences among KAP score categories were observed at all three phases. 


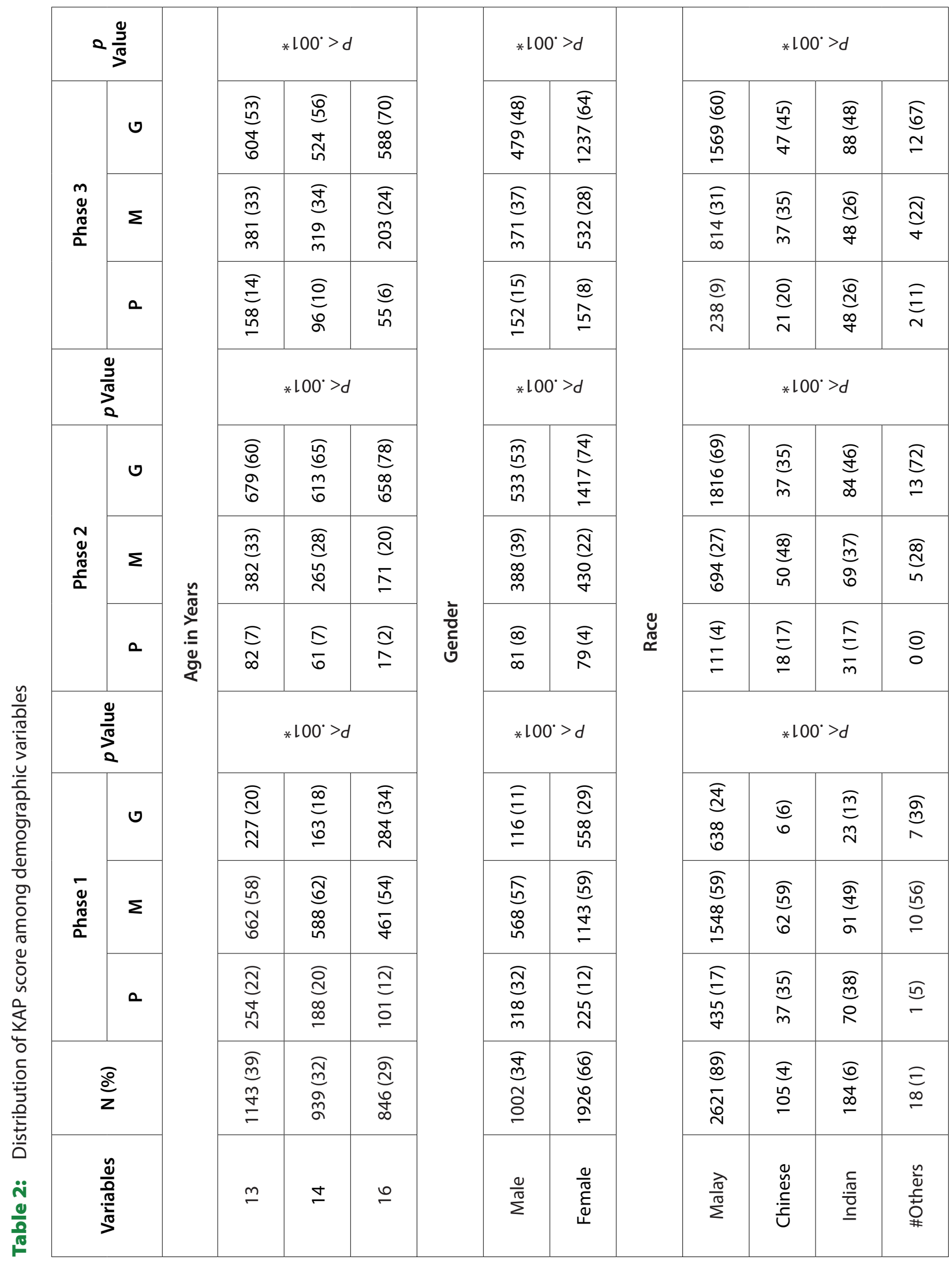




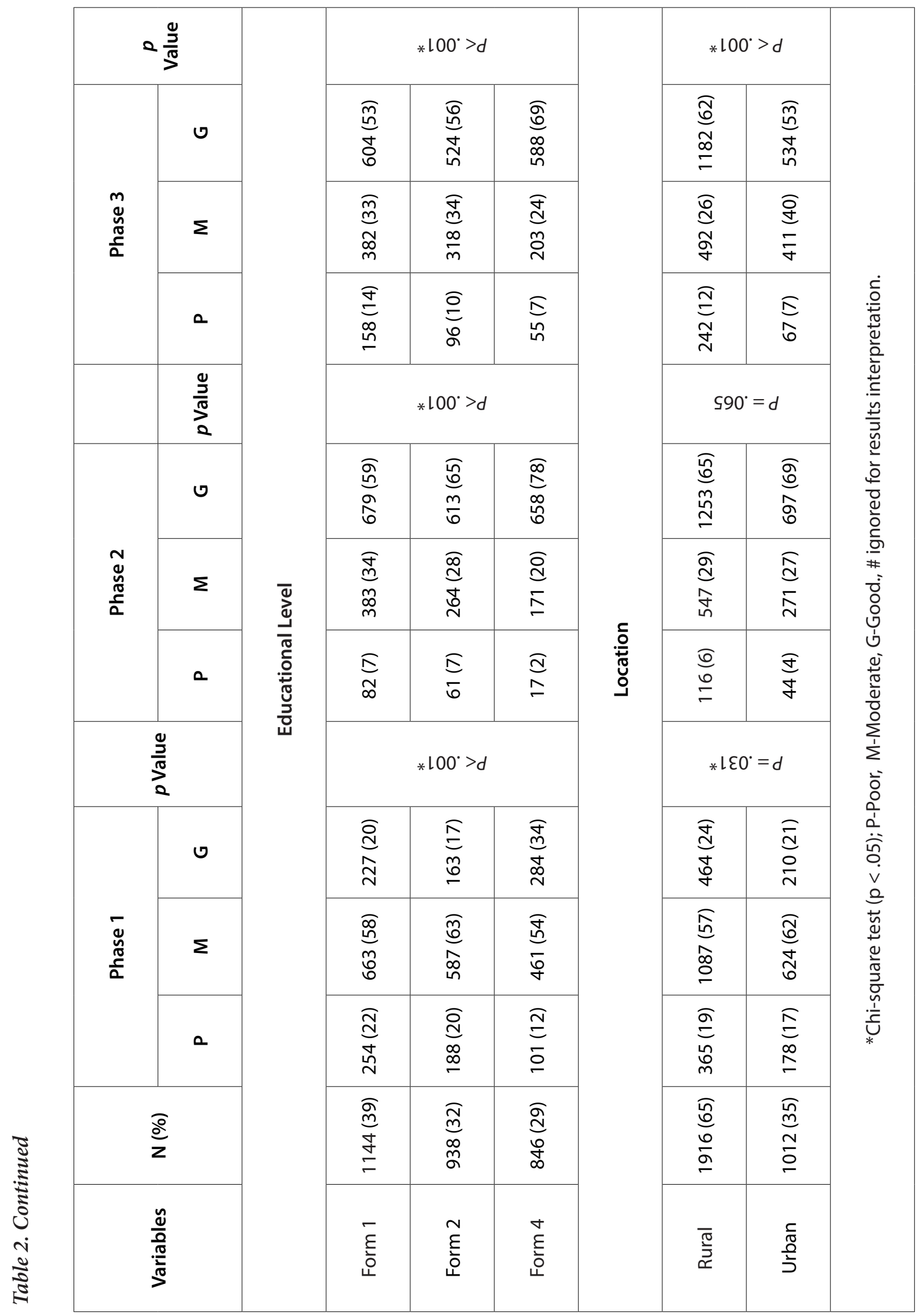




\subsection{Friedman's Test to Identify Total KAP Score Differences}

A non-parametric Friedman's test was run for KAP score differences and Kendall tau test to estimate the effect size. The Friedman test evaluated differences in median scores among the three phases $[X 2(2, \mathrm{~N}=2928)=1857$, $\mathrm{p}<.001]$ and Kindall coefficient, $(\mathrm{W}=.32)$ indicated fair agreement in differences among phases. Further, Friedman's mean rank indicated a relatively poor KAP score (1.37) at ph1, good KAP score (2.41) at ph2 and moderate KAP score (2.22) at ph3.

A post hoc, Wilcoxon signed rank test on the three pairs of contrasts was done to compare the differences in medians between pairs controlling for type-I error (significance level at $\mathrm{p}<.017$ ) across comparisons, the median KAP score difference and Bonferroni corrected ' $Z$ ' score at ph2 was significantly greater than ph1, [15(4) $>9(6), \mathrm{p}<.001],(\mathrm{Z}=40.4, \mathrm{~N}=2928, p<.001)$; ph3 was significantly greater than ph1 [15(7) > 9(6), p<.001], ( $Z$ $=31.1, \mathrm{~N}=2928, p<.001)$; and ph3 was significantly less than ph2, [15(7) < 15(4), p<.001], $(\mathrm{Z}=6.8, \mathrm{~N}=2928$, $p<.001)$ respectively.

\subsection{Effect of Educational Intervention for Knowledge Gain (ph1 vs. ph2)}

The pre-test vs. post-test (ph1 vs. ph2) results for the 18 items knowledge assessment are presented in Figure 1. The correct responses increased in all 18 items from preto post-test and showed highly significant differences in KAP scores using McNemars test $(\mathrm{p}<.001)$. The effect of 'Educational Pamphlets' was estimated from the difference in percentages of knowledge score between pre- and post-test which represents the knowledge gained due to intervention. The overall median knowledge score at ph1 and ph2 showed significant differences, 9(6) and 15(4) respectively, with a significant improvement of 6 points.

\subsection{Effect of Educational Intervention for Knowledge Retention (ph1 vs. ph3)}

Figure 2 presents the result of pre- and post-test, 3 to 6 months after intervention (ph1 and ph3). The number of correct responses increased in all 18 knowledge based items and showed highly significant differences in KAP scores which represent knowledge retained after 3 to 6

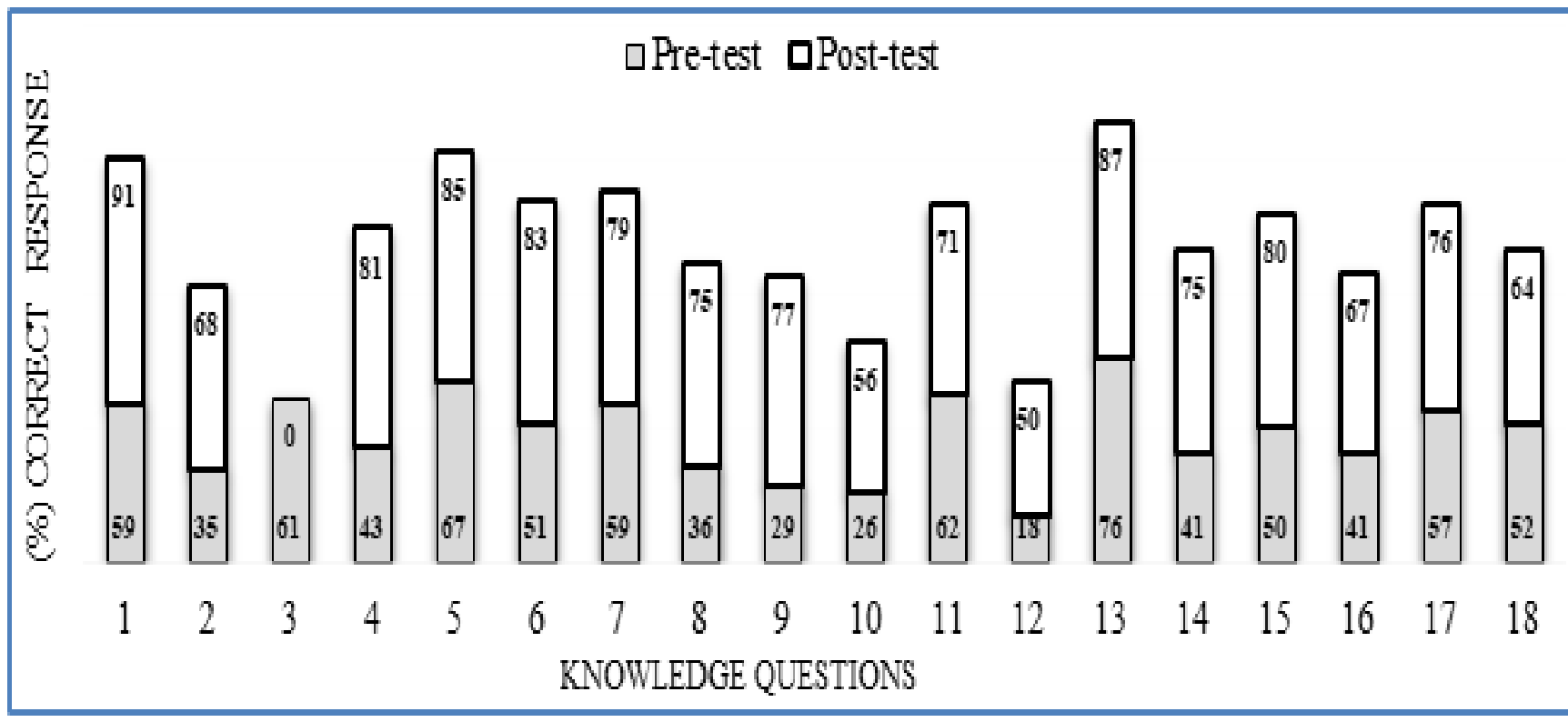

Fig. 1. . Comparison of knowledge gained, McNemars test based on binomial distribution shows $p<.001$ for all 18 items. 


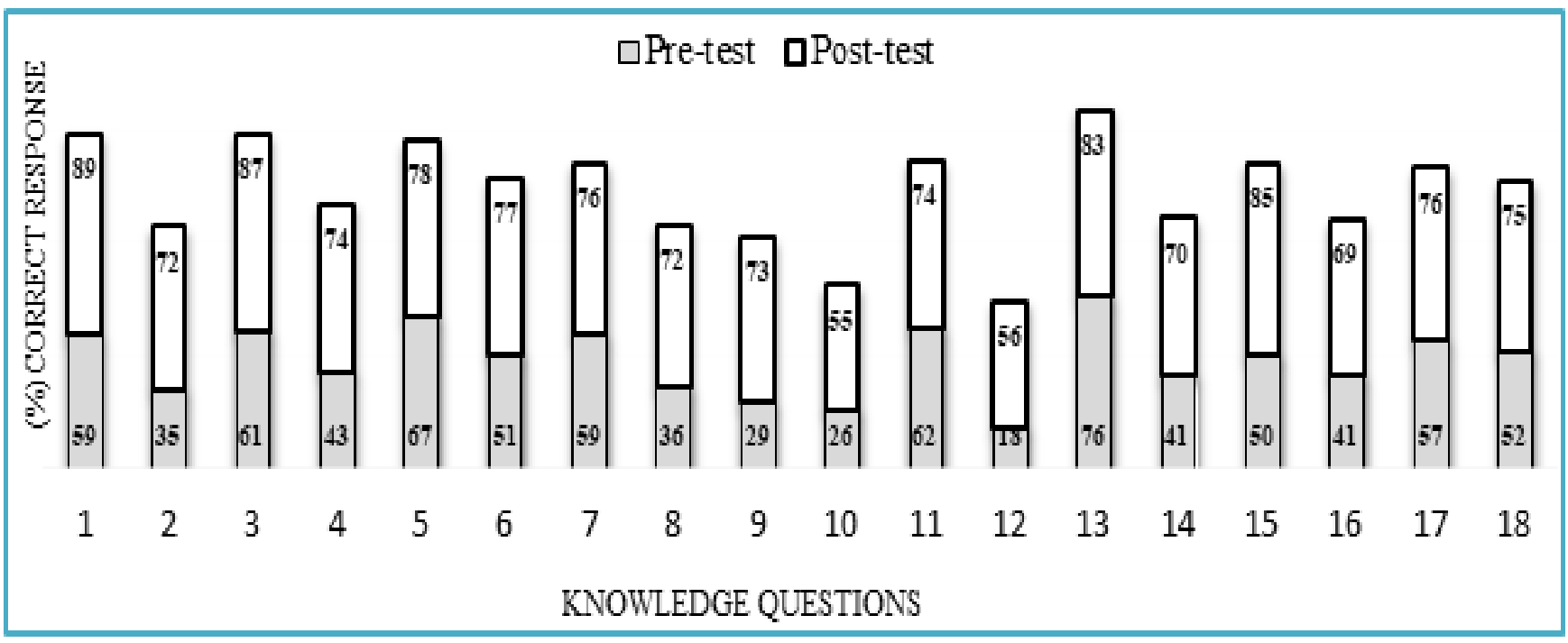

Fig. 2. Comparison of knowledge retention, McNemar test based on binomial distribution shows $p<.001$ for all 18 items.

months of intervention. The overall median knowledge score showed significant differences, 9(6) and 15(7) at ph1 and ph3 respectively which represents knowledge retained.

\subsection{Impact of Education Intervention (Pamphlet) on Total KAP Score}

A comparison of Knowledge, Attitude and Perception and KAP scores were done to estimate the impact of

Table 3: Comparison of correct response to K, AP and KAP outcomes at three time points

\begin{tabular}{|c|c|c|c|c|c|c|c|c|c|}
\hline \multirow[b]{2}{*}{ Categories } & \multicolumn{3}{|c|}{ Response to K-Items } & \multicolumn{3}{|c|}{ Response to AP-Items } & \multicolumn{3}{|c|}{ Response to KAP Items } \\
\hline & $\begin{array}{c}\text { ph1 } \\
\text { N (\%) }\end{array}$ & $\begin{array}{c}\text { ph2 } \\
\text { N (\%) }\end{array}$ & $\begin{array}{c}\text { ph3 } \\
\text { N (\%) }\end{array}$ & $\begin{array}{c}\text { ph1 } \\
\text { N (\%) }\end{array}$ & $\begin{array}{c}\text { ph2 } \\
\text { N (\%) }\end{array}$ & $\begin{array}{c}\text { ph3 } \\
\text { N (\%) }\end{array}$ & $\begin{array}{c}\text { ph1 } \\
\text { N (\%) }\end{array}$ & $\begin{array}{c}\text { ph2 } \\
\text { N (\%) }\end{array}$ & $\begin{array}{l}\text { ph3 } \\
\text { N (\%) }\end{array}$ \\
\hline $\begin{array}{c}\text { Poor/ } \\
\text { Negative }\end{array}$ & $\begin{array}{l}1848 \\
(63)\end{array}$ & $\begin{array}{l}513 \\
(18)\end{array}$ & $\begin{array}{l}727 \\
(25)\end{array}$ & $\begin{array}{l}544 \\
(18)\end{array}$ & $\begin{array}{c}232 \\
(8)\end{array}$ & $\begin{array}{l}551 \\
(19)\end{array}$ & $\begin{array}{l}543 \\
(19)\end{array}$ & $\begin{array}{l}160 \\
(5)\end{array}$ & $\begin{array}{l}309 \\
(10)\end{array}$ \\
\hline $\begin{array}{c}\text { Moderate/ } \\
\text { Neutral }\end{array}$ & $\begin{array}{l}715 \\
(24)\end{array}$ & $\begin{array}{l}538 \\
(18)\end{array}$ & $\begin{array}{l}338 \\
(11)\end{array}$ & $\begin{array}{l}1543 \\
(53)\end{array}$ & $\begin{array}{c}1059 \\
(36)\end{array}$ & $\begin{array}{l}1097 \\
(37)\end{array}$ & $\begin{array}{l}1711 \\
(58)\end{array}$ & $\begin{array}{l}818 \\
(28)\end{array}$ & $\begin{array}{l}903 \\
(31)\end{array}$ \\
\hline $\begin{array}{l}\text { Good/ } \\
\text { Positive }\end{array}$ & $\begin{array}{l}365 \\
(13)\end{array}$ & $\begin{array}{l}1877 \\
(64)\end{array}$ & $\begin{array}{l}1863 \\
(64)\end{array}$ & $\begin{array}{l}841 \\
(29)\end{array}$ & $\begin{array}{l}1637 \\
(56)\end{array}$ & $\begin{array}{l}1280 \\
(44)\end{array}$ & $\begin{array}{l}674 \\
(23)\end{array}$ & $\begin{array}{l}1950 \\
(67)\end{array}$ & $\begin{array}{l}1716 \\
(59)\end{array}$ \\
\hline Total & $\begin{array}{l}2928 \\
(100)\end{array}$ & $\begin{array}{l}2928 \\
(100)\end{array}$ & $\begin{array}{l}2928 \\
(100)\end{array}$ & $\begin{array}{l}2928 \\
(100)\end{array}$ & $\begin{array}{l}2928 \\
(100)\end{array}$ & $\begin{array}{l}2928 \\
(100)\end{array}$ & $\begin{array}{l}2928 \\
(100)\end{array}$ & $\begin{array}{l}2928 \\
(100)\end{array}$ & $\begin{array}{l}2928 \\
(100)\end{array}$ \\
\hline ph1-Pre & & & $\begin{array}{l}\text { Post } \\
\text { Knon }\end{array}$ & Atths & $\begin{array}{l}-K n \\
\text { hd } P\end{array}$ & $\begin{array}{l}\text { dge, AF } \\
\text { otion. }\end{array}$ & 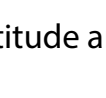 & ercep & KAP - \\
\hline
\end{tabular}


intervention as tabulated in Table 3. In ph1, the overall knowledge score was poor (63\%), attitude/perception was neutral (53\%) and KAP score was moderate (58\%). In ph2, the knowledge score was good (64\%), attitude/ perception was positive (56\%) and KAP score was good (67\%). It also observed a decrease in percentage of poor category at ph2 reflecting knowledge gain. The overall total KAP scores between ph1 and ph2 showed statistically significant differences and indicated the median KAP score was preferred more in ph2 $(\mathrm{Mdn}=$ 57), with Z score $=40.4, \mathrm{p}<.001$.

The knowledge retained was studied after three to six months of intervention (ph3). In ph3, the knowledge score was good (64\%), attitude/perception was positive (44\%) and KAP scores was good (59\%). The difference in knowledge score between ph1 and ph3 showed an increase which reflected the knowledge retained after three to six months. The overall total KAP scores between ph1 and ph3 showed statistically significant differences and indicated the median KAP score preferred ph3 (Mdn =56) over ph1 (Mdn = 47), $\mathrm{Z}=31, \mathrm{p}<.001$ (Table 3$)$.

\section{Discussion}

This longitudinal study was conducted for repeated measures at $0, .5$ and 3-6 months using educational pamphlet intervention among secondary school adolescents aged 13,14 and 16 years in Kedah state, Malaysia. Another Malaysian study reported similar aged study population ${ }^{18}$. The results endorse females, Malay and rural located respondents dominated the study population. Though the overall response rate of $23 \%$, $(\mathrm{N}=2$ 928/13000) could have posed a degree of nonresponse bias, studies have reported low response rates $(25 \%)$ for repeated measures in similar populations ${ }^{19}$.

\subsection{Differences in Knowledge and KAP}

The results showed that the KAP scores were significantly associated with all the demographic variables at all the three phases, except location at ph2. In 2010, Malaysia introduced the free national HPV immunization program for school girls aged $13^{20}$. This study is the first of its kind to investigate the KAP levels regarding HPV, five years after initiation of national HPV immunization program in Malaysia and among the HPV vaccinated adolescents, whereas a London based study reported a study on HPV knowledge after three years ${ }^{21}$.

This study found better knowledge scores among female respondents which were consistent with a study in Spain revealing (27\%) poor knowledge among males ${ }^{22}$. This study recorded moderate knowledge scores regarding HPV transmission (61\%) and its link to STD (61\%). The results were consistent with few local studies, though lower than an Italian study $(75 \%)^{22-24}$. This study also found, the adolescents had poor knowledge regarding the cause, vulnerability, consequences and treatment of HPV prior to intervention. Previous studies are in agreement with these findings ${ }^{23}$. The study found $29 \%$ adolescents from rural located schools had better knowledge on HPVs association with genital warts, comparable to a Spanish study ${ }^{22}$. Agreement of respondents to 'women infected with HPV are most likely to develop Cervical Cancer' was consistent (60\%) with one Malaysian study ${ }^{11}$ and lower than others $(80 \%$ and $69 \%)^{25-27}$. Rashwans report of $30 \%$ awareness on the role of Pap smear in CC prevention was consistent with our findings $(26 \%)^{11}$. Our study found 50\% awareness on HPV vaccine, whereas, other studies observed either very low, $10 \%$ and $6 \%$ in Sweden ${ }^{11,23}$ or moderately high awareness $(78 \%)^{25}$. An interesting contradiction was noted while assessing the respondents' intention for cancer prevention. They generally had a positive attitude and most of the respondents (75\%) were in favour of being vaccinated.

\subsection{Knowledge Gained and Knowledge Retained}

Overall, the median knowledge score at ph1 (baseline) were poor, 9(6)/18. The results were consistent with Italian, Sweden, Malaysian, Kenyan and subSaharan African studies reporting poor knowledge scores $^{23,24,28-32}$. This study was not in agreement and contradicted a Spanish report of $90 \%$ awareness on $\mathrm{HPV}^{22}$. At ph2, the median knowledge score was 
$15(4) / 18$. The results observed a increase in median knowledge score $9(6) \rightarrow 15(4)$. This denotes a substantial knowledge gain between baseline and intervention. The baseline knowledge disparity may be attributed to poor opportunities for awareness campaign about STIs or infectious diseases among adolescents which were not noted after receiving the protocol. This imparts the effectiveness of the pamphlet regardless of sociodemographic factors. At ph3, the median knowledge score was $15(7) / 18$. The results observed a decrease in percentage knowledge scores from $67 \% \rightarrow 59 \%$, median score $15(4) \rightarrow 15(7)$, indicating the tendency to forget information learned over time. The Friedman's mean rank score was good at ph2 (2.41) shifted to moderate (2.22) at ph3, a decline in knowledge retention among study population. Though expected under normal circumstances to forget information learned within three to four weeks, the study population showed significant knowledge retention over three to six months. The information involved is in one's own healthcare interest, which was found to be a promising outcome and encourage endorsing 'knowledge significantly predicts intention,' as reported by Rashwan ${ }^{33}$.

\subsection{Impact of Educational Intervention}

Intervention using pamphlets demonstrated, influencing perception and beliefs can substantially improve the knowledge level and significantly favour attitude towards prevention of HPV infections. A US study reported higher knowledge scores, $86 \%$ had higher intention to vaccinate compared to control among unvaccinated intervention group $^{34,35}$. A Germany study reported 'balanced health information leaflet' can increase knowledge of HPV and vaccination uptake" 31 . This study supported the use of pamphlets and demonstrated significant knowledge gain among respondents after intervention.

In this study, the repeated administration of same questionnaires may have acted as a trigger to prompt for information search regarding the infection which might have further initiated discussion between near and dear about its prevention and related cancers. A Finnish study noted, the survey questionnaire by itself can be a stimulus to provide knowledge. According to Health Belief Model (HBM), perceived threat is a combination of susceptibility and severity. All studies investigating the effectiveness of interventions, irrespective of the methods, aimed at a common goal, either to protect from STDs or to improve sexual health. Nearly, all intervention studies have reported a positive outcome, whatsoever tool (lecture, pamphlet, video, community interaction, etc.) were used ${ }^{30}$.

The major strength of this study is the incorporation of 3 to 6-months follow-up evaluation on KAP. In addition, the comparatively large sample-size, inclusion of both genders with rural and urban locations provides enough power for evaluating the usefulness of pamphlet for this study. Continuous health-education is the best approach to prevent Cervical Cancer from early adulthood which mostly depends on regular 'booster' sessions ${ }^{36}$. Nevertheless, the strongest measures of successful interventions should target the long-term outcomes which can reduce Cervical Cancer incidence and related mortality.

\section{Conclusion}

The KAP scores were comparatively poor at baseline and educational initiatives taken proved to be appropriate in increasing the awareness and enhancing beliefs towards HPV prevention. The study identifies the need for 'Spaced, Repetition-Based Educational Intervention' providing clear, precise and required information about the implications of HPV infection, addressing misconceptions, its prevention, fears of screening and importance of HPV vaccination. The strengths of this study include the use of repeated measure strategy to investigate a population-based sample for knowledge gained through intervention and knowledge retained after education for a period of three to six months.

\section{Study Limitation}

In spite of taking adequate care to follow the scientifically valid methods of representative samples, selection bias cannot be ruled out and as data were derived from survey 
that were self-reported and repeated measures, the data are susceptible to response and recall bias. There was no comparison group with which, we could have compared our study outcomes.

\section{Acknowledgement}

We are grateful to the Ministry of Secondary Education, Malaysia and Directorate of Secondary Education, Alor Setar for granting permission to conduct this study across secondary schools in Kedah state, Headmaster/ Headmistress and the counselling teachers of the participant schools for their support during the data collection process. We would also like to thank AIMST University, Malaysia for their moral and technical support and the study participants for their time and cooperation for this study.

\section{Implications}

Knowledge scores were moderate at baseline, significantly increased after educational intervention and substantially retained at 3-6 months. This study endorses' changing attitudes is a complex task and hard to influence.' Potential framework by policy makers, to implement 'Spaced, Repetition-Based Educational Intervention' at secondary school level will help reduce HPV related undue incidences.

\section{Author Contributions}

All authors contributed toward data collection, data entry, analysis, drafting and critically revising the manuscript and agree to be accountable for all aspects of the work.

\section{Disclosure}

The authors declare no conflicts of interest in this work.

\section{Supplementary Publications}

The preliminary studies of this research article has been published earlier under the titles "Development and
Validation of Human Papilloma Virus (HPV) infection and HPV vaccination questionnaire among young adults in Kedah state, Malaysia" and "Development and validation of 'Educational intervention tool' in prevention of Human Papilloma Virus (HPV) infection among adolescents -A pilot study"13,14.

\section{References}

1. Wong LP, Sam IC. Ethnically diverse female university students' knowledge and attitudes toward Human Papilloma Virus (HPV), HPV vaccination and Cervical Cancer. Eur J Obstet Gynecol Reprod Biol. 2010 Jan; 148(1): 90-5. PMid: 19910102. https://doi. org/10.1016/j.ejogrb.2009.10.002.

2. Lowy DR, Schiller JT. Reducing HPV-associated cancer globally. Cancer Prev Res (Phila). 2012; 5: 18-23. PMid: 22219162.

3. Sathiyasusuman A. Associated risk factors of STIs and multiple sexual relationships among youths in Malawi. PloS one. 2015 Aug; 10(8): e0134286. PMid: 26248328 PMCid: PMC4527764. https://doi. org/10.1371/journal.pone.0134286 .

4. Viens LJ. Human Papiloma Virus-associated cancersUnited States, 2008-2012. MMWR. Morbidity and Mortality Weekly Report. 2016; 65. https://doi. org/10.15585/mmwr.mm6526a1.

5. Abdullah AFL. Health and the Environment Journal (Hej): Mission statement. Health. 2016; 7:1.

6. Ezat WP, Aljunid S. Cost-effectiveness of HPV vaccination in the prevention of Cervical Cancer in Malaysia. Asian Pac J Cancer Prev. 2010 Aug; 11(1): 79-90. PMid: 20593935.

7. Zaridah S. A review of Cervical Cancer research in Malaysia. Med J Malaysia. 2014 Aug; 69(Suppl A): 33-41. PMid: 25417949.

8. Songthap A, Pitisuttithum P, Kaewkungwal J, Fungladda W, Bussaratid V. Knowledge, attitudes and acceptability of a Human Papilloma Virus vaccine among students, parents and teachers in Thailand. 
Southeast Asian J Trop Med Public Health. 2012 Mar; 43(2): 340-53. PMid: 23082586.

9. Bowyer HL, Marlow LA, Hibbitts S, Pollock KG, Waller J. Knowledge and awareness of HPV and the HPV vaccine among young women in the first routinely vaccinated cohort in England. Vaccine. 2013 Feb; 31(7): 1051-6. PMid: 23277094. https:// doi.org/10.1016/j.vaccine.2012.12.038 .

10. Chiang VC, Wong HT, Yeung PC, Choi YK, Fok MS, Mak OI, Wong HY, Wong KH, Wong SY, Wong YS, Wong EY. Attitude, acceptability and knowledge of HPV vaccination among local university students in Hong Kong. Int J Environ Res Public Health. 2016 May; 13(5): 486. PMid: 27187424 PMCid: PMC4881111. https://doi.org/10.3390/ ijerph13050486.

11. Rashwan H, Ishak I, Sawalludin N. Knowledge and views of secondary school students in Kuala Lumpur on Cervical Cancer and its prevention. Asian Pac J CancerPrev.2013 Jan; 14(4):2545-9. PMid: 23725172. https://doi.org/10.7314/APJCP.2013.14.4.2545 .

12. Kaliyaperumal KI. Guideline for conducting a Knowledge, Attitude and Practice (KAP) study. AECS Illumination. 2004 Jan; 4(1): 7-9.

13. Ali NA, Ping NY, Prajapati SK, Nazer ZA, Sarriff A. Development and validation of Human Papilloma Virus (HPV) infection and HPV vaccination questionnaire among young adults in Kedah state, Malaysia. Madridge J Pharm Res. 2017 Dec; 1(1): 33-9.

14. Ali AN, Ng YP, Prajapati SK, Sariff A, Nazer ZA. Development and validation of 'Educational intervention tool' in prevention of Human Papilloma Virus (HPV) infection among adolescents - A pilot study. Internat J of Inno Res and Knowl. 2017; 2(9): $38-50$.

15. Urrutia MT, Hall R. Beliefs about Cervical Cancer and Pap test: A new Chilean questionnaire. J Nurs
Scholarsh. 2013 Jun; 45(2): 126-31. PMid: 23452007. https://doi.org/10.1111/jnu.12009.

16. Chang IJ, Huang R, He W, Zhang SK, Wang SM, Zhao FH, Smith JS, Qiao YL. Effect of an educational intervention on HPV knowledge and vaccine attitudes among urban employed women and female undergraduate students in China: A cross-sectional study. BMC Public Health. 2013 Dec; 13(1): 916. PMid: 24088392 PMCid: PMC3852612. https://doi. org/10.1186/1471-2458-13-916.

17. Koo TK, Li MY. A guideline of selecting and reporting intraclass correlation coefficients for reliability research. J Chiropr Med. 2016 Jun; 15(2): 155-63. PMid: 27330520 PMCid: PMC4913118. https://doi. org/10.1016/j.jcm.2016.02.012 .

18. Jalani FF, Rani MD, Isahak I, Aris MS, Roslan N. Knowledge, Attitude and Practice of Human Papilloma Virus (HPV) vaccination among secondary school students in rural areas of Negeri Sembilan, Malaysia. Int J Collab Res Intern Med Public Health. 2016 Jun; 8(6): 56.

19. Wallander L, Tikkanen RH, Mannheimer LN, Ostergren PO, Plantin L. The problem of nonresponse in population surveys on the topic of HIV and sexuality: A comparative study. Eur J Public Health. 2014 Sep; 25(1): 172-7. PMid: 25223435. https://doi.org/10.1093/eurpub/cku154.

20. Ezat SW, Hod R, Mustafa J, Mohd D, Ahmad ZH, Sulaiman AS, Azman A. National HPV immunisation programme: Knowledge and acceptance of mothers attending an obstetrics clinic at a teaching hospital, Kuala Lumpur. Asian Pac J Cancer Prev. 2013; 14(5): 2991-9. PMid: 23803068. https://doi.org/10.7314/ APJCP.2013.14.5.2991 .

21. Bowyer HL, Marlow LA, Hibbitts S, Pollock KG, Waller J. Knowledge and awareness of HPV and the HPV vaccine among young women in the first routinely vaccinated cohort in England. Vaccine. 
2013 Feb; 31(7): 1051-6. PMid: 23277094. https:// doi.org/10.1016/j.vaccine.2012.12.038.

22. Navarro-Illana P, Diez-Domingo J, Navarro-Illana E, Tuells J, Aleman S, Puig-Barbera J. Knowledge and attitudes of Spanish adolescent girls towards Human Papiloma Virus infection: Where to intervene to improve vaccination coverage. BMC Public Health. 2014 Dec; 14(1): 490. PMid: 24885391 PMCid: PMC4061915. https://doi.org/10.1186/1471-245814-490.

23. Gottvall M, Tyden T, Hoglund AT, Larsson M. Knowledge of Human Papiloma Virus among high school students can be increased by an educational intervention. Int J Std Aids. 2010 Aug; 21(8): 558-62. PMid: 20975088. https://doi.org/10.1258/ ijsa.2010.010063.

24. Di Giuseppe G, Abbate R, Liguori G, Albano L, Angelillo IF. Human Papiloma Virus and vaccination: Knowledge, attitudes and behavioural intention in adolescents and young women in Italy. Brit J Cancer. 2008 Jul; 99(2): 225. PMid: 18628763 PMCid: PMC2480983. https://doi.org/10.1038/ sj.bjc.6604454 .

25. Rashwan H, Lubis SH, Ni KA. Knowledge of Cervical Cancer and acceptance of HPV vaccination among secondary school students in Sarawak, Malaysia. Asian Pac J Cancer Prev. 2011 Jan; 12(7): 1837-41. PMid: 22126576.

26. Al-Naggar RA, BobryshevYV, Al-JashamyK, Al-Musli M. Practice of HPV vaccine and associated factors among school girls in Melaka, Malaysia. Asian Pac J Cancer Prev. 2012; 13(8): 3835-40. PMid: 23098480. https://doi.org/10.7314/APJCP.2012.13.8.3835.

27. Abdullah F, Su TT. Enhancement of the Cervical Cancer screening program in Malaysia: A qualitative study. Asian Pac J Cancer Prev. 2010 Jan; 11(5): 1359-66. PMid: 21198293.

28. Wong LP. Knowledge and attitudes about HPV infection, HPV vaccination and Cervical Cancer among rural southeast Asian women. Int J Behav Med. 2011 Jun; 18(2): 105-11. PMid: 20524163. https://doi.org/10.1007/s12529-010-9104-y .

29. Awadh AI, Hassali MA, Al-Lela OQ, Bux SH, Elkalmi RM, Hadi H. Does an educational intervention improve parents' knowledge about immunization? Experience from Malaysia. BMC Pediatrics. 2014 Dec; 14(1): 254. PMid: 25284603 PMCid: PMC4287312. https://doi.org/10.1186/1471-2431-14-254.

30. Fu LY, Bonhomme LA, Cooper SC, Joseph JG, Zimet GD. Educational interventions to increase HPV vaccination acceptance: A systematic review. Vaccine. 2014 Apr; 32(17): 1901-20. PMid: 24530401 PMCid: PMC4285433. https://doi.org/10.1016/j. vaccine.2014.01.091.

31. Wegwarth O, Kurzenhauser-Carstens S, Gigerenzer G. Overcoming the knowledge-behavior gap: The effect of evidence-based HPV vaccination leaflets on understanding, intention and actual vaccination decision. Vaccine. 2014 Mar; 32(12): 1388-93. PMid: 24486360. https://doi.org/10.1016/j. vaccine.2013.12.038.

32. Perlman S, Wamai RG, Bain PA, Welty T, Welty E, Ogembo JG. Knowledge and awareness of HPV vaccine and acceptability to vaccinate in sub-Saharan Africa: A systematic review. PloS one. 2014 Mar; 9(3): e90912. PMid: 24618636 PMCid: PMC3949716. https://doi.org/10.1371/journal.pone.0090912 .

33. Rashwan HH, Saat NZ, Manan DN. Knowledge, attitude and practice of Malaysian medical and pharmacy students towards Human Papiloma Virus vaccination. Asian Pac J Cancer Prev. 2012; 13(5): 2279-83. PMid: 22901207. https://doi.org/10.7314/ APJCP.2012.13.5.2279.

34. Marek E, Dergez T, Rebek-Nagy G, Kricskovics A, Kovacs K, Bozsa S, Kiss I, Ember I, Gocze P. Adolescents' awareness of HPV infections and attitudes towards HPV vaccination 3 years following the introduction of the HPV vaccine in Hungary. 
Vaccine. 2011 Nov; 29(47): 8591-8. PMid: 21939711. https://doi.org/10.1016/j.vaccine.2011.09.018.

35. Kester LM, Shedd-Steele RB, Dotson CA, Zimet GD. 13. Effects of a Brief Educational Intervention on HPV Knowledge and Vaccination Intent. J Adolesc Health. 2013 Feb; 52(2): S26-7. https://doi. org/10.1016/j.jadohealth.2012.10.067.
36. Scott-Sheldon LA, Fielder RL, Carey MP. Sexual risk reduction interventions for patients attending sexually transmitted disease clinics in the United States: A meta-analytic review, 1986 to early 2009. Ann Behav Med. 2010 Jul; 40(2): 191-204. PMid: 20652778 PMCid: PMC2939227. https://doi. org/10.1007/s12160-010-9202-8. 